\title{
MULTIPLE PATHS TO ADOPTION: THE ROLE OF ACTORS IN THE APPROPRIATION OF JAPANESE WORK SYSTEMS
}

\section{(Published in Asian Business and Management, 2002, 1: 353-372)}

\begin{abstract}
This paper builds on the context-dependent view of work systems diffusion within the manufacturing context across conflicting governance structures. It adopts an integrated understanding into the social constitution of work systems. There is an appreciation of the role of strategic choice, beliefs and power in the adoption of alternative work systems. The study is founded on a systematic comparative study of the ways in which alternative work systems are adopted and sustained in the UK subsidiary firms of two Japanese MNCs. It concludes that there is a multiplicity of adoption processes rather than a 'onebest-solution' to organising resources. Taking into account the complex ensembles of routines that can mould what is being communicated across national boundaries, the adoption process is displayed as an active process involving actors' decisions to accept new ideas, where the links between implementation and internalisation processes are important in determining the outcome of the diffused system.
\end{abstract}

Keywords: adoption, work systems diffusion, embeddedness, neo-institutionalism, Japanese systems 


\section{Introduction}

The vital importance of work systems diffusion in today's competitive climate has been widely canvassed (e.g. Mowery et al., 1996). The goals of diffusing work systems are commonly seen as the requirement for adaptation and improved efficiency in times of change (e.g. Marceau, 1992). In its link to learning, work systems diffusion can be taken as "a purposive quest to retain and improve competitiveness, productivity, and innovativeness in uncertain technological and market circumstances" (Dodgson, 1993:378). The paradigm in which the diffusion of work systems within international collaborations is discussed is commonly economic (e.g. Kogut and Zander, 1992; Bresman et al., 1999). There is an attempt in such studies to link knowledge with a performance outcome. In this sense, the firm is treated as a repository of capabilities and competence, and knowledge is seen as an objectified commodity. The social dimension of work systems diffusion, which is situated, contingent and context-dependent, is not given due attention in the economic view. Furthermore, the limits to diffusion and the embeddedness of work systems in institutional settings are not acknowledged. In contrast, there is a growing consensus among neo-institutionalists that the institutional environment is an important influential factor with regard to inter-organisational structures (e.g. Hollingsworth et al., 1994). Although a number of cross-national comparative studies on this subject have shown variation in the adoption of work systems across different governance structures (e.g. Lane, 1996), evidence from these studies is confined to the macro level. The dynamics of how diffused work systems are shaped within the firm have received less attention. The diffusion of work systems embedded in institutional processes and organisational members' mental constructs and norms of 
conduct (Child and Rodrigues, 1994) can be constrained by the regularised patterns of human interaction in organisations. An attempt is made in this paper to complement the national level discussions with the firm level by providing an analysis of the social patterns that shape the diffusion process. Both 'structure and flow' aspects of the diffusion process are addressed (Sorge, 1996). In other words, this study examines not only structures, but also workers' response to those structures. It acknowledges the idea that employees are a vital component of work systems. This idea rests on the premise that "technology [cannot] be separated from the knowledge, skills, and motivation of the workforce" (Cutcher-Gershenfeld et al., 1998:viii). Similarly, it acknowledges the idea that "structures, such as institutions or rules, cannot be separated from the concrete microlevel social action in which they are implicated" (Karnøe and Nygaard, 1999:82).

The paper is organised into four sections. The following section discusses two distinct views of work systems diffusion: the objectified and context-dependent views. The study adopts the context-dependent view of work systems diffusion, and addresses the limits to adoption of alternative work systems in cross-national settings. In the third section, research method and sites are discussed. In the fourth section, characteristics that are critical in the selected firms' adoption of source companies' work systems are presented through a systematic comparison of cases, and the role of actors in the editing of work systems is highlighted. The final section draws attention to the multiplicity of adoption processes in the diffusion of work systems across nations. 


\section{The Objectified View of Work Systems Diffusion}

The traditional view on work systems diffusion reflects the interest in structure and technology where tangible characteristics are taken as the primary sources of competitive advantage. However, "individuals act according to what is meaningful for the individuals interacting in and constituting those situations in the flow of daily life" (Karnøe and Nygaard, 1999:83). The complex set of meanings attached to work systems shapes the way in which structure and technology are interwoven in organisational practice. At one extreme, which is partly reflected by the information technology/knowledge management view, researchers have argued for technological determinism within a contingency framework where particular kinds of technology yield certain predictable outcomes (e.g. Womack et al., 1990). This extreme composes the more linear, mechanistic view of diffusion, where work systems are seen as imported from, or adopted out of a 'foreign' context in a unitary fashion. Within this view, the diffusion of work systems is seen as a consequence of "deliberate organisational redesign (usually by managers) to accommodate conflicting pulls from local and imported patterns, to improve the internal fit within the organisation and fit with external environment and to improve organisation's performance" (Westney, 1999:402). This has led to debates on convergence of institutional systems that become uniform or isomorphic with the globalisation of managerial structures and strategies.

According to Kenney and Florida (1993), the most successful firms use teams, quality control activities, rotation and egalitarian management styles. These constitute 'one-best- 
solution' to organising resources, and assessing technology, know-how, managerial expertise, capital and international markets. This thinking is especially reflected in the early instances of adoption of Japanese work systems, characterised by the diffusion of one or two particular management techniques, in isolation from the broader strategy and philosophy by UK management (Beale, 1994). Work systems, in this context, are taken to be communicated between the sender or the broadcaster and the receiver in a form abstracted from the wider social networks. The complex ensembles of routines that can mould what is being 'communicated' are ignored. Knowledge ingrained in work systems is rather understood as an object that can be created, packaged and diffused, more or less unchanged, from one context to another. The theoretical assumption is that key variables, such as structure and technology, move without friction and in a linear fashion (Clark, 1987). The assumption that variables move in a linear fashion implies that learning occurs in a mimetic or a coercive fashion, and that best practice is diffused through imitation. However, in practice, such variables are shaped by organisational culture and value systems, hence, are sensitive to contexts.

Other researchers have challenged the "sharp decrease in attention to people management and development issues, and step increase in attention to information technology (IT), information systems (IS) and intellectual capital” (Swan, 1999:4), seeing technological and structural characteristics of work systems as embedded in a social set of norms and beliefs. They pay heed to the context-dependent nature of work systems. In contrast to the objectified view of work systems diffusion, the context-dependent view acknowledges 
the stickiness of work systems and, in turn, the limits to diffusion across different institutional contexts.

\section{Context-dependent View of Work Systems Diffusion}

The discussions on the diffusion of work systems within the manufacturing context have commonly centred on technical issues such as the cost and quality advantages of reduced inventory and efficiency gains from concurrent engineering. The definition adopted here diverges from privileging organisational structures and technological systems as the driving forces of work systems diffusion. Work systems are conceptualised as "premised on harnessing the knowledge at the point where products are made or services are delivered" (Cutcher-Gershenfeld et al., 1998:69). This conceptualisation emphasises the importance of intangible aspects within a process, in addition to acknowledging the tangible aspects.

Work systems, rooted as they are in firms' co-ordination mechanisms and organisational routines, incorporate the cognitive dimension, that is beliefs, perceptions, ideals, values, emotions and mental models, that is taken-for-granted (Takeuchi, 1998, http://www.sveiby.com/articles/LessonsJapan.htm). Particular means of solving problems, carrying out tasks and arriving at decisions become institutionalised over time with the influence of past and present actions, beliefs and interests (Clark and Mueller, 1994). 
The context-dependent view of work systems diffusion considers the plurality of actors, role of social structures, unintended outcomes of power struggles and problems with removing existing practices in the diffusion of work systems. For instance, perceptions of adopters reveal that innovations are "heterogeneous complexes rather than homogeneous entities" (Clark, 1987:60), hence their diffusion is understood to be non-linear. Firmspecific work systems are shaped by patterns of "knowing as a dynamic activity involving the continuous creation, reproduction, modification and destruction of streams of meaning" (Marshall and Sapsed, 2000:2). In contrast to the emphasis on structural and technical concerns within the objectified view of work systems diffusion, there is a focus on active processes involving "the formation, redesign and implementation of new ideas" within the context-dependent account (Hislop et al., 1998:429).

The present study builds on the context-dependent view of work systems diffusion. It adopts an integrated understanding or insight into the social constitution of work systems, paying heed to the interrelated aspects of technology, structure (i.e. largely the tangibles), and people, training, discipline, management-worker relations and social networks (i.e. largely the intangibles) in a process. A firm's knowledge can be "continually re(constituted) through the activities undertaken within the firm" (Tsoukas, 1996:22). Hence, it is proposed in the paper that the role of actors in shaping work systems is important. Empirical evidence is provided to integrate actors into action and to combine action with constraints by highlighting the limits to the diffusion process. 
There is a dynamic interaction among episodes of external acquisition of knowledge, its use by firms and the commitment by firms to the extent that the acquired knowledge assumes a taken-for-granted or institutionalised nature. The institutionalised nature of work systems is achieved when "the employees at the recipient unit attach to the practice symbolic meaning and value, as have the employees from the home country" (Kostova, 1999:311). This is labelled as the internalisation process in the study. Triggered by operational and/or strategic motivations, work systems are acquired and put to use by management. The role of management is observed in the implementation of work systems. Furthermore, the acceptance of alternative work systems within firms points to the translation of existing work systems by employees that results in appropriated work systems or the blending of new work systems with the existing ones.

Figure 1 shows the impact of the key local institutional, organisational and group characteristics (indicated by the thicker arrows) on the degree of implementation and internalisation of alternative work systems.

Take in Figure 1

It is proposed here that local institutional factors, such as the location site and skills base of the workforce in the area, organisational characteristics, such as the nature of alternative work systems, and group characteristics, such as the attitudes of teams towards diffused systems, can be important underlying factors in the degree to which alternative work systems are implemented and internalised. Work systems are defined in 
this study as organisational practices that are the product of over three decades of continuous improvement in Japan, driven by people's knowledge, ideas and suggestions. The nature of these practices is conceptualised as structural (i.e. shift to team structure), cultural (i.e. value and norms that constitute the philosophies which underlie the structural and technical elements of continuous improvement schemes such as emphasis on training), control-related (i.e. perceived exercise of power) and technological (i.e. advanced production systems technology that is needed for the efficient running of technical systems). The tangible foundation of continuous improvement schemes is operationalised here as the structural and technological work systems that are generally abstracted from their contexts to reflect explicit forms of knowledge. The intangible foundation of continuous improvement schemes is operationalised as the cultural and control-related work systems. The association of an exercise of control with the intangible foundation of continuous improvement schemes is based on the argument that the Japanese tend to exercise implicit forms of control (i.e. social investment that extends well beyond hierarchical principles) that may be less resisted by employees than explicit forms of control such as direct supervision (McMillan, 1996).

The context-dependent nature of the diffusion of work systems is explored through a comparative study of two affiliate firms of Japanese MNCs in the UK.

\section{Research Methods and Sites}

The study draws on a two-step comparative historical analysis that combines detailed case studies of two companies, hereon labelled as Teniki UK and Nissera UK (both 
pseudonyms), with systematic comparison to highlight the necessary and unnecessary conditions for the internalisation of Japanese parent companies' work systems. In Djelic's (1998:14) words, detailed case studies ensure that "historical and contextual singularities are not being disregarded", and systematic comparison "allows for a significant theoretical leverage and represents a powerful tool, thus making generalisation possible". The cases are selected with the intention to include affiliate firms of Japanese MNCs in different local institutional sites in a comparative study. The research focuses on participants' perceptions of continuous improvement activities and related structural changes. One should bear in mind that the research details influential characteristics that are identified through a multilevel analysis. It is a holistic study that is limited to analysing the combined influence of characteristics at macro and micro levels.

The field research draws on 40 open-ended and semi-structured interviews ${ }^{1}$ conducted between 1998 and 2000 with Japanese advisors, directors, UK team leaders, operators and managers across personnel and training, sales and marketing, product engineering, design and quality, finance, and purchasing in the UK sites. Participant observation in the UK subsidiary firms over one week, which enabled the researcher to be sensitive to the context-dependent, specific nature of the diffused work systems, complements the interviews. Information is also gathered through factory tours and interviews conducted with the Japanese managers (two at Teniki and six at Nissera) in international operations, production, general affairs, quality assurance, corporate finance, engineering, and corporate planning and control functions in Japan. The type of information sought is 
concerned with the meaning for individuals of events, relationships, social structures, roles and norms.

Teniki UK was owned by a British firm before being acquired by a Japanese car component manufacturer, Teniki, in 1996. The UK subsidiary employs 170 people and is located in a centre for tourism, where large portion of the labour force (38.8 per cent in 1997) is employed in the public sector. Teniki UK's senior management was replaced with a more market-oriented, quality-conscious team upon its acquisition. Since 1996, there have been six Japanese advisors in the technical and development, operations, sales and marketing areas. Having no line responsibility, they are brought in from the parent company to act as technical experts, avoiding hierarchical position as a control and filter mechanism. The people side of management is left to local managers.

The second case company, Nissera UK, was founded in 1988, as part of a strategy to serve major Japanese customers in Europe. It is established on a greenfield site located in a centre for manufacturing, where the manufacturing base accounts for 38.5 per cent of the jobs in the area. The company employs 300 people (in 1999). Its senior management team changed composition during the initial years of its foundation from having 60 per cent Japanese employees to the current six per cent. There are 12 Japanese managerstwo senior directors, eight managers in the engineering area and two managers in the financial area-serving liaison roles between the subsidiary and parent company. The production management and supervision are predominantly British and recruited locally. 
Both Teniki UK and Nissera UK employ continuous improvement in quality and reliability through a programme of total quality improvement, serving their customers' needs Just-In-Time.

The following section provides a comparison of the structural, cultural, control-related and technological work systems that are diffused to Teniki UK and Nissera UK in an attempt to highlight the multiplicity of paths to adopting alternative work systems.

\section{Multiple Paths to Adoption}

Conscious efforts to institutionalise meanings, values and norms produce considerable differences with regard to the degree of implementation and internalisation across the two cases in the UK automotive sector. The observed differences are associated with the variation in key local institutional, organisational and group characteristics (see Table 1).

Take in Table 1

An analysis of the key characteristics at the local institutional, organisational and group levels, as presented in the following sections, can provide a robust explanation of the context-dependent nature of work systems diffusion.

\section{i. Local Institutional Context}

In line with Sharpe's (1997) arguments, this study suggests that the absence of a preexisting culture on the greenfield site of Nissera UK facilitates the internalisation of 
highly institutionalised Japanese practices, as the new workforce has fewer preconceptions about different ways of operating. Hence, a new set of work procedures can be introduced with comparatively less resistance. Nissera UK can also employ a skilful workforce due to its location in a centre for manufacturing. Organisational inertia tends to lead to practices that more closely resemble local practices on a brownfield site than on a greenfield site. There seems to be a pull for 'local isomorphism' at the brownfield site of Teniki UK (Ferner and Quintanilla, 1998). In other words, there are normative and cognitive constraints on alternative structures and processes that the Teniki UK workforce can consider.

The degree of internalisation of Japanese work systems appears to be high where there is a favourable local institutional context characterised by location on a greenfield site and a high skills base, as that at Nissera UK. In contrast to what is depicted in the literature (e.g. Elger and Smith, 1994), a large supply of low skilled workers and location in a centre for tourism (as exemplified by Teniki UK), where labour can be expected to be relatively free of preconceived ideas in manufacturing, tend not to facilitate the internalisation of Japanese work systems. Where there is location on a brownfield site and low skills base in the area, as with Teniki UK, the degree of internalisation of Japanese work systems tends to be low.

The following sections consider the operational and strategic motivations of management in the implementation of work systems and employees' values and interests in the internalisation of alternative work systems. 


\section{ii. Organisational Context}

\section{Organisational Structure: The Shift to Team Structure}

There has been a shift in the organisational structure of Teniki UK and Nissera UK towards a flatter team structure. This has had an impact on worker response to diffused work systems. Although the operators at the two subsidiary firms are cynical with regard to the structural transition, those at Nissera UK have been more successful in adopting a team-based structure than those at Teniki UK.

Given the segregation between management and workers, the shift to a team structure at Teniki UK has met a challenge. The company faces difficulty in instilling high levels of commitment among operators. As for Nissera UK, the experience of a shift to a team structure in 1997, upon the build-up of skills imparted by Japanese expatriates in the early years of the company's establishment, is better received by operators than at Teniki UK. However, fluid job descriptions evident in the Japanese parent company are not widely observed in the UK subsidiary. Operators perceive team leaders as above the work group rather than as members of the team. Unlike the situation at the parent company, team leaders and assistants have clearly defined responsibilities and their positions are treated as managerial ones at Nissera UK. This is reflected in Production Manager's (30 July 1999) claim that "team leaders do not do the work. As long as they make sure the system is in, what comes out is efficiency, cost and quality”. As Iwata (1982:52) notes, "unlike the American-style [or in this case the UK-style] companies where the institutional structure is quite logically arranged on the basis of clearly defined individual tasks, work is allocated to sections and divisions in Japanese companies". This seems to 
validate the argument that it is common practice for firms to mimic the tangible parts of work systems, such as the structural elements, and fail to recognise the intangible cultural elements, such as team spirit, that are integral to the operation of the system (CutcherGershenfeld et al., 1998).

Although, both firms found it difficult to develop and replicate 'esprit de corps', Nissera UK has, in relative terms, been more successful in running team-based activities such as quality circles. In addition to the length of time that the team structure has been in place, Nissera UK employs a more skilled workforce and is provided with long-term financing by the parent company. Unlike that at Teniki UK, Japanese managers have offered handson training to operators and have been heavily involved in shop-floor activities. In other words, Japanese expatriates at Nissera UK have attempted to carry over the institutional co-operation feature of their business system that encourages investment in skill development into the UK system (e.g. Orrù, 1997). In spite of what may be seen as adversarial industrial relations in the area in which Nissera UK is located, the human resource practices of Japanese expatriates in the early years of establishment resulted in a sense of shared commitment between workers and management.

\section{Organisational Culture: Commitment to Quality Improvement Schemes}

In line with the suggestions in the literature, pre-existing set of strategies, structures and technologies shape the pattern of change towards the 'Japanese model' (Fligstein, 1990). In the given cases, actual activities do not conform to the prescriptions of practices implemented in Japan, and diffused work practices are renegotiated and adapted. For 
example, older workers at Teniki UK work according to their own rules and enjoy the freedom created by a weak control mechanism in the factory. They jig machines when they do not work properly, fill in production time sheets at the end of the day rather than on an hourly basis and manipulate scrap rate figures. The role of actors in editing existing work systems can be observed especially in cases where the nature and degree of Japanese investment is indirect and low.

I believe, people [direct labour] understand that they need to cut costs in the business. However, the adoption of the approaches and the ownership of correcting the problems, they do not do. That again is partly through training and the pressure on the business, not being able to release them to train because the first thing we need to do to is keep our customer happy. We had a massive delivery problem when I joined. We are now sort of 99.9 per cent day in day out. Now that that is stabilised, we can go back to people. $\quad$ (British Operations Manager, 18 January 2000)

The experience of developing interdependency, trust and shared knowledge is unique to a specific workplace, context and group of people (Cutcher-Gershenfeld et al., 1998). This is exemplified by Teniki UK and Nissera UK, which have had difficulty imparting source company's continuous improvement activities, such as discipline in the workplace and ' $5 \mathrm{C}$ housekeeping' ${ }^{2}$ principles, by securing the commitment of all parties to the process. The ability of team leaders in the two subsidiary firms to maintain effective communication within and across teams, and to motivate operators to engage in continuous improvement activities seems to be influenced in part by the institutional variation in worker commitment and flexibility that exists between Japan and the UK. Unlike in Japan, a minimum involvement philosophy has been the tradition in the UK 
(Dore, 1973). Continuous improvement schemes are implemented, even though they are not fully internalised, at Nissera UK, whilst they have failed at Teniki UK. In other words, there have been attempts to extract parts of the continuous improvement system for transplantation in the UK subsidiary. The Japanese belief that "good housekeeping should provide an environment conducive to improved work habits, quality and care of facilities" (Schonberger, 1982:67) is not felt by operators and those enforcing the system at Teniki UK. For instance, "people do not read the quality audits. They just put a check. Somebody at the end of the day should look at the sheets" (senior operator in Air Element). The low skills level of the workforce at Teniki UK, due to its location in a centre for tourism rather than manufacturing, appears to have a negative impact on the internalisation of parent company's practices. At Nissera UK, the implementation of continuous improvement schemes has not yet been fully internalised by the operators, given the way local management administers Kaizen initiatives. Initiatives mediated by the orientation of British management are less straightforward in their effects.

We were forced to go on this course [on quality circles]. They called it a 'family circle'. It is a big joke. Everything is a joke. It could be better if they were straighter with us. As long as we are concerned, they have deceived us. They will start with something and if it does not suit them, they will change it. (Operator in cluster assembly at Nissera UK)

It is questionable to what degree local management has understood the importance of intangible elements in quality control (QC) efforts. The UK affiliate firms seem to have a limited ability to generate "organisational cultures, involving high levels of worker 
commitment and flexibility" (Warner, 1994:510), which underlie the technical and structural elements of continuous improvement schemes.

At Nissera UK, management had a strong approach to discipline until 1997. Strong attention paid to the implementation of continuous improvement schemes, in addition to availability of financial and human resources, meant that the level of commitment to such schemes was higher at Nissera UK than it was at Teniki UK. George and Levie (1984) argue that limited emphasis on training and waning interest in QCs for not delivering the quick savings expected are frequently cited as reasons for the failure of QCs in the UK. At Nissera UK, the hands-on training of operators by the Japanese in the initial years of the company's establishment taught the operators the skills of 'an apprentice' working with his/her 'master' and learning a 'craft', "not through language but through observation, imitation and practice" (Nonaka and Takeuchi, 1995:63). However, Japanese management's training, supervisory and advisory roles have reduced over the years at Nissera UK as the phase of implementing new management systems and practices in the organisation has been completed. Currently, weaker attention is paid to the implementation of continuous improvement principles with the replacement of Japanese expatriates by local management. "Although, they had more strict rules, Japanese managers would help you work. They would go to the source of the problem. British managers make up titles and waste money" (operator in Printed Circuit Board manufacture at Nissera UK). 
Control Mechanism: Degree of Involvement by the Japanese

The internalisation of Japanese work systems is also influenced by the control mechanism which complements structural and cultural practices that are diffused. The cases in question suggest that the nature of management intervention in the implementation of Japanese work systems is crucial in shaping the internalisation process. Such intervention points to the active process of internalisation involving actors' decisions to accept new ideas.

Although the extent to which Japanese expatriates are involved in day-to-day running of the business and manpower planning differs across the two cases, the pressure exerted on the technical and strategic side of affairs is considerable in the two subsidiary firms. At Teniki UK, there is high and indirect involvement by Japanese management in the activities of the affiliate firm. There is also financial pressure from the parent on Teniki UK in terms of demands for rapid profitability, despite the interest on the parent company's part to develop skills at the UK operation. This arises from Teniki's lack of flexibility in financial control over the UK division's activities due to the role of a major Japanese car manufacturer in its operations.

The way the company development has been financed has restricted that [the adoption of Japanese practices]. Japanese normally take a very longterm view in any investment. They are always for the future. For some reason, the way this business has been financed is through short-term loans instead of a large-share capital by the parent company. And the request has been that we make a very quick return on the investment whereas normally you would have maybe a few years' grace. (Operations Manager at Teniki UK, 18 January 2000) 
This points to the impact of contextual factors such as the form of ownership on the adoption of Japanese systems, which is commonly ignored in the literature on crossnational diffusion of work systems. In contrast to what is commonly cited in the literature (e.g. Sako and Sato, 1997), Teniki UK receives short-term financing from the Japanese parent company. As the cases here show, a long-term outlook to development tends to be more facilitating in the degree to which Japanese works systems are internalised at the UK affiliate firm than a short-term perspective. By the same token, the parent company of Nissera UK is heavily involved in its subsidiary's decisions with regard to providing technology and finances for investment. However, Nissera has not exerted stringent budgetary control over its UK division. Nonetheless, in general, there has been high and direct level of control on Nissera UK since its establishment. Nissera has exercised personal/cultural control through direct supervision and expatriate control (Harzing, 2000). As the responsibility for design rests with parent companies, the two subsidiary firms operate more as assembly operations, dependent on imports of manufactured inputs from Japan (Elger and Smith, 1994).

The degree to which the Japanese management is involved in the activities of the adopter firms relates to the availability of Japanese expatriates and their roles in the UK adopter firms. For example, Teniki UK has a lower number of Japanese expatriates available for training and strategic and technical decision-making. 


\section{Technology Diffusion}

Teniki UK and Nissera UK, in comparison to their parent companies, are not profound examples of advanced technology. As opposed to George and Levie's (1984:26) argument that "the Japanese industry is not leagues 'ahead' of us in terms of use of robots and automated equipment", there is evidence from the cases to suggest that the Japanese parent companies are more technologically advanced than their UK subsidiary firms in at least the automotive manufacture industry. In spite of the low diffusion of technology to adopter firms such as to Nissera UK, the degree of internalisation of work systems is relatively high due to an emphasis on a structural and cultural shift. This seems to suggest that technology is secondary to the people problems of implementing Japanese work systems. It is also reflective of the Japanese emphasis on the 'soft' dimension of management (Pascale and Athos, 1996). Culture, commitment, motivation, involvement and trust emerge as being more important than technology in the internalisation of continuous improvement schemes.

Teniki and Nissera's willingness to diffuse technology and know-how to their UK subsidiary firms is greater where there is a high level of perceived competence, an ability to develop one's knowledge base and successful performance in terms of strong financial status on the part of the subsidiary firm. For example, "since 1993, Nissera UK has had bad profits. They could not manufacture anymore. Nissera brought manufacturing, such as product machine part, from Japan to UK [sic]. Since then, Nissera has minimised know-how transfer" (Quality Assurance Manager at Nissera, 13 April 2000). Furthermore, it is believed that "they [Nissera UK] do not need advanced technology or 
know-how. They cannot meet customers' advanced expectation", as "they [Nissera UK] do not understand our product [instrumentation]. They understand the manufacturing process, how to move the instrument, but cannot see the bigger picture, how to fit the product" (ibid.). The cases suggest that the long-term orientation of Japanese MNCs to diffusing know-how weakens as the UK affiliate firms fail to develop their own knowledge base and satisfactory financial results.

Work systems are embedded in and diffused through social relationships and interactions. The diffusion process entails sharing understandings through the synthesis and interaction of team members rather than "about moving knowledge around from person to person so that each expands their range of knowledge" (Swan, 1999:10). In the cases concerned, Japanese expatriates serve as influential actors in the diffusion of the parent companies' work systems to the UK affiliate firms. They serve to promote particular kinds of practices among members of the social system.

\section{iii. Group Context}

Attitude of Teams towards Continuous Improvement Schemes

The distinctive patterns of work system characteristics of task control, workplace relations and employment practices and the level of commitment that these characteristics support differ between Japan and the UK. Of the two companies, Teniki UK displays a lower level of commitment to alternative work systems. Its group norms reflect a British tendency to question authority in contrast with the Japanese subtle hierarchy of 'harmony and family unity' (e.g. Lincoln, 1990). There is resistance to continuous improvement 
schemes, noticeably among the older Teniki UK operators who have been with the company before its acquisition by Teniki. "You sometimes get the wrong kind of people, non-team players. They can argue and not fit in. They are mostly older ones with fixed ideas" (middle-aged operator in the Air Element at Teniki UK). The lack of commitment among some of the older operators on the shop floor appears to be due in part to the preference for the old traditional British manufacturing system of union activity and craftsmanship. A senior carbon canister assembler perceives the problem in the effectiveness of the system as the outcome of different institutional processes in Japan and the UK: "it [housekeeping] is ingrained in Japan. It goes back a long way. The European continental approach is different. Production, sweeping and paperwork represent three separate jobs". In other words, production is carried out by the operator, sweeping by the apprentice and paperwork by the supervisor. "We need the trade union down here to improve the work environment" (senior operator in Air Element at Teniki UK).

Although Nissera UK is perceived by management as proficient in quality management, researcher's work experience in the factory shows inconsistency in the priority given to quality standards by operators. "Getting assembly operators to do what you want is difficult in the UK. In Japan, they are very dedicated, 100 per cent committed" (Cell3 Team Leader in Cluster Assembly at Nissera UK, 15 June 1999). For example, quality checks in Cell2 are flimsy. The SPC data are manipulated to give the impression to management that measurements fall within control limits when they are clearly outside tolerance levels. Moreover, quality tests that take seven minutes to complete on fuel and 
temperature indicators are halted after two to three minutes as the seven-minute duration is found to be too long. Similarly, forms that are filled in on Cell2 rejects and reworks are frequently recorded as 'other supplier's fault' rather than 'self responsibility' or 'machine fault'. The low sense of personal responsibility felt in this cell tends to have a negative impact on the overall quality of products and customer relations.

We supply many products to [our biggest customer]. We know that the 100 components from Nissera will be good. We cannot be so sure at Nissera UK. The control system is not so different from Nissera. For instance, the process quality control chart is the same as that at Nissera. Over the past two years we have tended to go back to the Japanese parts. Every single part needs to meet quality standards. In the UK, the attitude is, out of million, surely there can be few defects. There is a wider tolerance level in European supplier context. This is not the case in Japan. Customers, unlike in the UK, expect zero defects in Japan.

(Japanese Quality Director at Nissera UK, 13 September 1999)

In spite of the Japanese-perceived low commitment to QC programmes, Nissera UK operators have internalised the QC principles to a greater extent than Teniki operators. This appears to be related to greater financial stability and high and direct involvement of the Japanese in operator training. Moreover, the skills level of Nissera UK workforce is higher than that at Teniki UK, and the company is located on a greenfield site: "we can easily select manufacturing staff. People can understand our requirements...In the beginning, we asked for a lot of help from the local staff, so we could not provide job descriptions. A brownfield site is more disadvantageous from that perspective" (Japanese Corporate Planning and Control Manager at Nissera, 14 April 2000). 
In summary, both Teniki UK and Nissera UK exemplify the way in which a firm only selectively utilises and draws upon production practices identified with the 'Japanese model' (Taylor et al., 1994). Compromise solutions are common where only technical aspects of the 'Japanese model' are adopted, and conflicting institutional legacies hinder the diffusibility of work systems.

\section{Conclusion: The Appropriation of Work Systems in Diffusion}

The paper draws a distinction between the objectified and the context-dependent view of work systems diffusion, whereby the former model presumes that the only problems worth considering are inside the user firm at the stage of implementation. This study adopts the latter view in an attempt to investigate the diffusibility of meaning, value attached to work systems. It suggests that where the original meaning of the source company's practices is difficult to diffuse, the existing work practices are likely to be redefined and restructured until eventually they become routine. The argument that work systems can be treated as an object that is created, packaged and moved in an unchanged form from one unit to another in a communications model (Hislop et al., 1998) is rejected. Rather, it is suggested that a practice becomes infused with value when it is accepted and approved by employees (Kostova, 1999).

The research findings suggest that firms attempt to locally interpret alternative work systems rather than submit to environmental pressures toward isomorphism. There is support for the argument that the adoption of work systems by an organisation is importantly determined by the extent to which the system is institutionalised (Tolbert and 
Zucker, 1983). Incompatibility in institutionalised patterns of operating is not necessarily shaped by technical efficiency criteria. There is an enactment through social patterns of interaction.

The paper presents multilevel influences on the internalisation of Japanese work systems. There is, thus, not a focus on social patterns of interaction at the firm level alone. There is an attempt to highlight the structural determinants of work systems diffusion, as well as the process of internalisation within organisations. The paper shows the following influences on work systems diffusion: (i) the adopter firm characteristics, (ii) the nature of diffused work systems and (iii) the local institutional context to which the work systems belong.

The reshaping of practices depends not only on institutional differences between work systems that are embedded in distinct local and national contexts, but also on organisational characteristics, such as demographics, logistics and financial stability (Clark and Mueller, 1994). The comparative analysis of internalisation of work systems has shown that, far from convergence arguments, there is the reshaping of continuous improvement schemes in a new institutional setting.

\section{References}

Beale D (1994). Driven by Nissan? A Critical Guide to the New Management Techniques. London: Lawrence and Wishart.

Bresman H, Birkinshaw J, Noel R (1999). Knowledge transfer in international acquisitions. Journal of International Business Studies 30(3): 439-462. 
Child J, Rodrigues, S (1994). The role of social identity in the international transfer of knowledge through joint ventures. Research Paper, Judge Institute of Management Studies, University of Cambridge, Cambridge.

Clark P (1987). Anglo-American Innovation. New York: Walter de Gruyter.

Clark P, Mueller F (1994). Organisations and nations: From universalism to institutionalism? Research Paper, Aston Business School, Aston University, Birmingham.

Cutcher-Gershenfeld J, Nitta M, Barret BJ, Belhedi N, Chow SS, Inaba T, Ishino I, Lin W, Moore ML, Mothersell WM, Palthe J, Ramanand S, Strolle ME, Wheaton AC (1998). Knowledge-Driven Work: Unexpected Lessons from Japanese and United States Work Practices. Oxford University Press: Japan Business and Economic Series.

Djelic ML (1998). Exporting the American Model: The Post-war Transformation of European Business. Oxford: Oxford University Press.

Dodgson M (1993). Organisational learning: A review of some literatures. Organisation Studies 14(3): 375-394.

Dore R (1973). British Factory-Japanese Factory: The Origins of National Diversity in Industrial Relations. Oxford: University of California Press.

Elger T, Smith C (1994). Global Japanisation? The Transnational Transformation of the Labour Process. London: Routledge.

Ferner A, Quintanilla J (1998). Multinationals, national business systems and HRM: The enduring influence of national identity or a process of 'Anglo-Saxonisation'. The International Journal of Human Resource Management 9(4): 710-731.

Fligstein N (1990). The Transformation of Corporate Control. Cambridge, Massachusetts: Harvard University Press.

George M, Levie H (1984). Japanese Competition and the British Workforce. London: Centre for Alternative Industrial and Technological Systems (CAITS).

Harzing AWK (2000). An empirical test and extension of the Bartlett and Ghoshal typology of multinational companies. Journal of International Business Studies 31(1): 101-120.

Hislop D, Newell S, Scarbrough H, Swan J (1998). Innovation and networks: Linking diffusion and implementation. International Journal of Innovation Management 1(4): 427-448.

Hollingsworth JR, Schmitter PC, Streeck W (1994). Governing Capitalist Economies: Performance and Control of Economic Sectors. Oxford: Oxford University Press. 
Iwata R (1982). Japanese-style Management: Its Foundations and Prospects. Tokyo: Asian Productivity Organisation.

Karnøe P, Nygaard C (1999). Bringing social action and situated rationality back in: Toward an understanding of the constitution of business systems. International Studies of Management and Organisation 29(2): 78-93.

Kenney M, Florida R (1993). Beyond Mass Production: The Japanese System and Its Transfer to the US. New York: Oxford University Press.

Kogut B, Zander U (1992). Knowledge of the firm, combinative capabilities and the replication of technology. Organisation Science 3(3): 383-397.

Kostova T (1999). Transnational transfer of strategic organisational practices: A contextual perspective. Academy of Management Review 24(2): 308-324.

Lane C (1996). The social constitution of supplier relations in Britain and Germany: An institutionalist analysis. In: Whitley R, Kristensen PH (eds). The Changing European Firm: Limits to Convergence. London: Routledge. pp 271-304.

Lincoln JR (1990). Japanese organisation and organisation theory. In: Staw B, Cummings L (eds). Research in Organisational Behaviour 14. Greenwich, Connecticut: JAI Press. pp 255-294.

Marceau J (1992). Reworking the World: Organisation, Technologies and Cultures in Comparative Perspective. Berlin: De Gruyter.

Marshall N, Sapsed J (2000). The limits of disembodied knowledge: Challenges of interproject learning in the production of complex products and systems. Paper presented at the Knowledge Management: Concepts and Controversies Conference, 10-11 February, University of Warwick, Coventry.

McMillan CJ (1996). The Japanese Industrial System, third edition. Berlin: De Gruyter.

Mowery D, Oxley J, Silverman B (1996). Strategic alliances and inter-firm knowledge transfer. Strategic Management Journal 17, Winter Special Issue: 77-91.

Nonaka I, Takeuchi H (1995). The Knowledge-Creating Company: How Japanese Companies Create the Dynamics of Innovation. New York: Oxford University Press.

Orrù M (1997). Institutional co-operation in Japanese and German capitalism. In: Orrù M, Biggart NW, Hamilton GG (eds). The Economic Organisation of East Asian Capitalism. Thousand Oaks, California: Sage Publications. pp 311-339.

Pascale RT, Athos AG (1986). The Art of Japanese Management. London: Penguin Books Ltd. 
Sako M, Sato H (1997). Japanese Labour and Management in Transition. London: Routledge.

Schonberger RJ (1982). Japanese Manufacturing Techniques: Nine Hidden Lessons in Simplicity. New York: The Free Press.

Sharpe DR (1997). Compromise solutions: A Japanese multinational comes to the UK. In: Whitley R, Kristensen PH (eds). Governance at Work: The Social Regulation of Economic Relations. Oxford: Oxford University Press. pp 171-189.

Sorge A (1996). Societal effects in cross-national organisation studies: Conceptualising diversity in actors and systems. In: Whitley R, Kristensen PH (eds). The Changing European Firm. London: Routledge. pp 67-86.

Swan J (1999). Introduction. In: Scarbrough H, Swan J (eds). Case Studies in Knowledge Management. London: Institute of Personnel and Development. pp 1-12.

Taylor, B, Elger, T, Fairbrother, P (1994). Transplants and emulators: The fate of the Japanese model in British electronics. In Elger T, Smith, C (eds). Global Japanisation? The Transnational Transformation of the Labour Process. London: Routledge. pp 196225.

Tolbert PS, Zucker LG (1983). Institutional sources of change in the formal structure of organisations: The diffusion of civil service reform, 1880-1935. Administrative Science Quarterly 28(1): 22-39.

Tsoukas H (1996). The firm as a distributed knowledge system: A constructionist approach. Strategic Management Journal 17, Winter Special Issue: 11-25.

Warner M (1994). Japanese culture, Western management: Taylorism and human resources in Japan. Organisation Studies 15(4): 509-533.

Westney DE (1999). Organisation theory perspectives on the cross-border transfer of organisational patterns. In: Liker JK, Fruin WM, Adler PS (eds). Remade in America: Transplanting and Transforming Japanese Management Systems. New York: Oxford University Press. pp 385-408.

Womack JP, Jones DT, Roos D (1990). The Machine that Changed the World. New York: Macmillan. 
Figure 1. The Diffusion of Work Systems with a Process Dimension

\section{Local Institutional Level (I)}

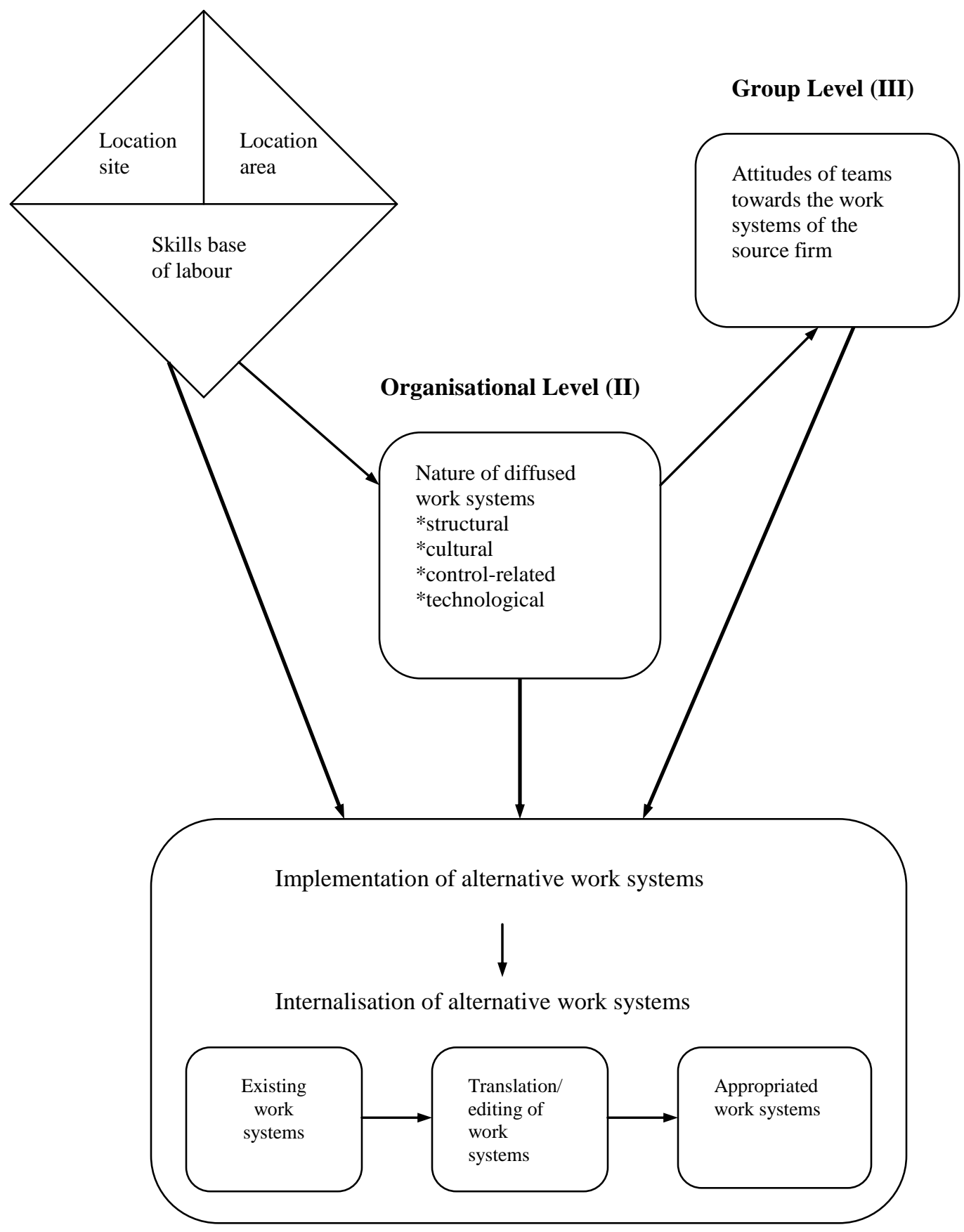

Source: Adapted from Kostova (1999) 
Table 1. The Degree of Implementation and Internalisation at Teniki UK and Nissera UK

\begin{tabular}{|l|l|c|c|}
\hline \multirow{2}{*}{$\begin{array}{l}\text { Degree of } \\
\text { implementation } \\
\text { and internalisation }\end{array}$} & Teniki UK & Nissera UK \\
\cline { 2 - 4 } & Implementation & Low & High \\
\cline { 2 - 4 } & Internalisation & Low & Medium \\
\hline
\end{tabular}

\begin{tabular}{|c|c|c|c|}
\hline \multirow[t]{2}{*}{$\begin{array}{l}\text { Local institutional } \\
\text { context }\end{array}$} & $\begin{array}{ll}\text { Location } & \text { site } \\
& \text { area }\end{array}$ & $\begin{array}{l}\text { Brownfield } \\
\text { Centre for tourism }\end{array}$ & $\begin{array}{l}\text { Greenfield } \\
\text { Centre for } \\
\text { manufacturing }\end{array}$ \\
\hline & Skills base & $\begin{array}{l}\text { Low in } \\
\text { manufacturing }\end{array}$ & $\begin{array}{l}\text { High in } \\
\text { manufacturing }\end{array}$ \\
\hline \multirow[t]{7}{*}{$\begin{array}{l}\text { Company } \\
\text { characteristics }\end{array}$} & Size (as of 1999) & $\begin{array}{l}\text { Medium } \\
\text { (170 employees) }\end{array}$ & $\begin{array}{l}\text { Medium } \\
\text { (300 employees) }\end{array}$ \\
\hline & $\begin{array}{l}\text { Age } \\
\text { (from the year of } \\
\text { acquisition/ } \\
\text { establishment } \\
\text { to data collection) }\end{array}$ & $\begin{array}{l}3 \text { years } \\
(1996-1999)\end{array}$ & $\begin{array}{l}11 \text { years } \\
(1988-1999)\end{array}$ \\
\hline & $\begin{array}{l}\text { Nature of work } \\
\text { (in 1999) }\end{array}$ & $\begin{array}{l}\text { Assembly of } \\
\text { carbon canister } \\
(37 \%), \\
\text { Air Intake Systems } \\
(35 \%)\end{array}$ & $\begin{array}{l}\text { Assembly of } \\
\text { instrument clusters } \\
\text { for automobiles } \\
(83 \%), \\
\text { Motorcycles } \\
(13 \%), \\
\text { construction } \\
\text { machines }(4 \%)\end{array}$ \\
\hline & Form of ownership & $\begin{array}{l}\text { Subsidiary } \\
\text { relationship, } \\
57 \% \text { of Teniki } \\
\text { shares held by } \\
\text { Japanese car } \\
\text { manufacturer }\end{array}$ & $\begin{array}{l}\text { Subsidiary } \\
\text { relationship, } \\
\text { Parent company is } \\
\text { not owned by a car } \\
\text { manufacturer }\end{array}$ \\
\hline & Terms of financing & $\begin{array}{l}\text { Short-term } \\
\text { orientation }\end{array}$ & $\begin{array}{l}\text { Long-term } \\
\text { orientation }\end{array}$ \\
\hline & $\begin{array}{l}\text { Number of Japanese } \\
\text { expatriates and their } \\
\text { roles in the UK }\end{array}$ & $\begin{array}{l}4 \text { (MD is British) } \\
\text { Advisory role }\end{array}$ & $\begin{array}{l}12 \text { (including MD) } \\
\text { Mainly director role }\end{array}$ \\
\hline & $\begin{array}{l}\text { Skills level of the } \\
\text { workforce }\end{array}$ & Low & Medium \\
\hline
\end{tabular}




\begin{tabular}{|c|c|c|c|}
\hline \multirow[t]{4}{*}{$\begin{array}{l}\text { Organisational } \\
\text { Context }\end{array}$} & $\begin{array}{l}\text { Nature of the } \\
\text { diffused practices } \\
\text { - Organisational } \\
\text { structure }\end{array}$ & $\begin{array}{l}\text { Shift to team } \\
\text { structure in } 1999\end{array}$ & $\begin{array}{l}\text { Shift to team } \\
\text { structure in } 1997\end{array}$ \\
\hline & $\begin{array}{l}\text { - Organisational } \\
\text { culture: } \\
\text { Commitment to } \\
\text { continuous } \\
\text { improvement } \\
\text { schemes } \\
\text { * Emphasis on } \\
\text { training }\end{array}$ & Low & $\begin{array}{l}\text { High (till } \\
\text { 1997)/Medium } \\
\text { thereafter }\end{array}$ \\
\hline & $\begin{array}{l}\text { - Control-related: } \\
\text { Degree of } \\
\text { involvement by the } \\
\text { Japanese }\end{array}$ & High, Indirect & High, Direct \\
\hline & $\begin{array}{l}\text { - Technological: } \\
\text { Technology } \\
\text { diffusion }\end{array}$ & Low & Low \\
\hline Group Context & $\begin{array}{l}\text { Attitude of teams } \\
\text { towards diffused } \\
\text { work systems: level } \\
\text { of commitment }\end{array}$ & Low & Medium \\
\hline
\end{tabular}




\section{Endnotes}

1. 18 of the interviews were conducted at Teniki UK, whilst the remaining 14 were carried out at Nissera UK.

2. These constitute classifying, clarifying, cleanliness, clean-up and custom. 